\title{
Anna GaWeŁ
}

Uniwersytet Jagielloński

\section{SZKOŁA I NAUCZYCIEL WOBEC WSPÓŁCZESNYCH WYZWAŃ PROMOCJI ZDROWIA DZIECI I MŁODZIEŻY}

\begin{abstract}
Abstrakt: Promocja zdrowia w szkole obejmuje edukację zdrowotną oraz działania zmierzające do tworzenia środowiska fizycznego i psychospołecznego sprzyjającego zdrowiu uczniów. Proces ten warunkują czynniki edukacyjne, organizacyjne, związane z kompetencjami nauczyciela oraz społeczno-kulturowe, które tworzą w rzeczywistości współczesnej szczególny kontekst podejmowanych przez szkołę działań. Autorka dokonuje analizy założeń programowych szkolnej edukacji zdrowotnej, programów kształcenia akademickiego nauczycieli w zakresie edukacji zdrowotnej oraz wybranych aspektów funkcjonowania środowiska szkoły, upatrując w nich bariery ograniczające efektywność szkolnej promocji zdrowia.
\end{abstract}

Słowa kluczowe: promocja zdrowia, edukacja zdrowotna, szkoła.

\section{WPROWADZENIE}

Zagadnienia dotyczące zdrowia, jego uwarunkowań oraz możliwości ochrony i wzmacniania są współcześnie nie tylko przedmiotem zainteresowania medycyny i wielu pozamedycznych dyscyplin naukowych, ale także ważnym obszarem politycznego i społecznego dyskursu. Niemal powszechna już świadomość potęgujących się wraz z postępem cywilizacji i towarzyszącymi mu przemianami w stylach życia człowieka zagrożeń dla jego zdrowia powoduje, że chyba nikt dziś nie kwestionuje potrzeby podejmowania działań promujących zdrowie na wszystkich poziomach życia społecznego, począwszy od polityki globalnej po społeczność lokalną i funkcjonujące $w$ jej ramach instytucje życia publicznego. Jedną z nich jest szkoła, która - będąc najważniejszym po rodzinie środowiskiem socjalizacji 
i wychowania młodego człowieka - powinna go wspierać w prowadzącym ku dojrzałości wielostronnym rozwoju. Nie ulega wątpliwości, że zdrowie jest fenomenem warunkującym przebieg tegoż rozwoju we wszystkich jego wymiarach (por. Gaweł 2014, s. 12), toteż poszukiwanie odpowiedzi na pytania dotyczące uwarunkowań, wyzwań, zasobów i ograniczeń procesu promocji zdrowia w szkole jest $\mathrm{z}$ pożądane i w pełni uzasadnione zarówno w ramach teorii, jak i praktyki pedagogicznej.

Z pojęciem "promocji zdrowia” i związanej z nią edukacji zdrowotnej wiąże się duży polimorfizm definicji i znaczeń, który wynika z tego, że są one przedmiotem zainteresowania różnych gałęzi nauki oraz obszarem działań w wielu sferach życia społecznego, a także ze zróżnicowania zawodowego osób, dla których zagadnienia zdrowia i choroby są wpisane w zakres profesjonalnej działalności. Dla jasności prowadzonego wywodu należy zatem na wstępie dookreślić przyjęty tu sposób interpretacji tych kluczowych pojęć i osadzić je w kontekście działań szkoły.

W odniesieniu do pojęcia „promocji zdrowia” za punkt wyjścia przyjmuję definicję zaproponowaną na I Międzynarodowej Konferencji Promocji Zdrowia w Kanadzie, w której określa się promocję zdrowia jako proces umożliwiający ludziom zwiększenie kontroli nad swoim zdrowiem w sensie jego poprawy i utrzymywania jak najdłużej na jak najwyższym poziomie oraz w sensie sprawowania samokontroli i samoopieki w zdrowiu i chorobie w całym cyklu życia przez dokonywanie wyborów i podejmowanie decyzji sprzyjających zdrowiu (WHO 1986). W ujęciu tym podkreśla się, że o przejęciu przez ludzi kontroli nad własnym zdrowiem decydują umiejętności określania swoich potrzeb zdrowotnych oraz dostęp do warunków umożliwiających zaspokajanie tych potrzeb. Celem działań podejmowanych $\mathrm{w}$ ramach promocji zdrowia jest $\mathrm{w}$ związku $\mathrm{z}$ tym $\mathrm{z}$ jednej strony wyposażenie jednostek i grup w wiedzę i umiejętności, czemu ma służyć edukacja zdrowotna jako element konstytutywny promocji zdrowia, z drugiej zaś stwarzanie warunków, które umożliwią ludziom nie tylko właściwe reagowanie w sytuacjach zagrożenia zdrowia, ale także przejawianie na co dzień zachowań spełniających kryteria aktywności prozdrowotnej (por. Gaweł 2013). Przedstawione ujęcie promocji zdrowia pozwala przyjąć, że

promowanie zdrowia w szkole jest procesem ukierunkowanym na umacnianie i potęgowanie potencjałów zdrowia uczniów, który obejmuje edukację zdrowotną oraz działania zmierzające do tworzenia w szkole sprzyjającego zdrowiu środowiska w jego wymiarze fizycznym i psychospołecznym (Gaweł 2014, s. 80).

Takie spojrzenie wyznacza sposób interpretacji „edukacji zdrowotnej”, zgodnie z którym jest ona traktowana jako pojęcie podrzędne w stosunku do „wychowania 
zdrowotnego". Zakres znaczeniowy tak rozumianej „edukacji zdrowotnej” obejmuje zatem wszelkie świadome i celowe działania o charakterze dydaktycznym, których efektywność jest uwarunkowana odpowiednio dobraną technologią, to jest zasadami, formami, metodami i środkami dydaktycznymi (de Tchorzewski 2006).

W przeprowadzanych tu analizach nadrzędnym, a zarazem kluczowym zagadnieniem uczyniona zostanie promocja zdrowia w szkole, zaś szkolna edukacja zdrowotna będzie traktowana jako jej nieodłączny i konstytutywny komponent.

\section{STAN ZDROWIA DZIECI I MŁODZIEŻY SZKOLNEJ WYZWANIEM DLA PROMOCJI ZDROWIA}

Potrzeba podejmowania działań w zakresie promocji zdrowia uzasadniana jest z jednej strony stanem zdrowia społeczeństwa (mierzonym za pomocą wskaźników częstotliwości występowania chorób i zgonów), zwłaszcza w odniesieniu do chorób cywilizacyjnych, z drugiej zaś możliwością przeciwdziałania niekorzystnej sytuacji epidemiologicznej dzięki działaniom pozamedycznym. Ponadto wskazuje się, że zdrowie jest fundamentalnym dobrem osobistym i zasobem dla społeczeństwa gwarantującym jego pomyślny rozwój ekonomiczny oraz że posiadanie stanu zdrowia możliwego do uzyskania na miarę indywidualnej determinacji biologicznej jest jednym z podstawowych praw każdego człowieka.

W odniesieniu do dzieci i młodzieży szkolnej podkreśla się, że zdrowie jest zasobem, który nie tylko warunkuje harmonijność zachodzących w okresie adolescencji przemian rozwojowych, lecz także determinuje poziom osiągnięć szkolnych i przebieg procesu wychowania. Stwarzanie warunków do prowadzenia efektywnych działań w zakresie promocji zdrowia i związanej z nią edukacji zdrowotnej uczniów jest w tym kontekście jednym z podstawowych zadań szkoły.

$\mathrm{Na}$ liście argumentów przemawiających za potrzebą podejmowania działań służących promowaniu zdrowia wśród dzieci i młodzieży umieszczane są m.in.:

- pogarszające się wskaźniki sprawności fizycznej i nadmiernej masy ciała. Wyniki prowadzonych badań pokazują, że wskaźniki sprawności fizycznej dzieci i młodzieży szkolnej (wytrzymałości i siły ramion, wytrzymałości biegowej, siły mięśni brzucha, gibkości) lokują się poniżej norm opracowanych dla poszczególnych grup wiekowych, zaś występowanie nadwagi i otyłości stanowi obecnie w Polsce narastający

\footnotetext{
1 Przyjmuję, że zakres znaczeniowy pojęć „edukacja zdrowotna” oraz „wychowanie zdrowotne” jest wyznaczany stopniem jednorodności pojęć „edukacja” i „wychowanie”, z którego wynika określony między nimi stosunek podrzędności (por. Rubacha 2003).
} 
lawinowo problem zdrowotny, określany już mianem epidemii². Oprócz konsekwencji społecznych wymienione zaburzenia powodują szereg dolegliwości somatycznych, m.in.: przeciążenia układu kostno-stawowego, skłonność do alergii, bezdech nocny, w tym często nieodwracalnych powikłań ujawniających się w dorosłym życiu, np. choroby układu krążenia, cukrzycę typu II (Jarosz 2013);

- narastające zjawisko wadliwego funkcjonowania młodych ludzi w sferze psychospołecznej (deficyty w zakresie kompetencji społecznych, agresja, wandalizm, wczesna inicjacja seksualna);

- niepokojąca skala zaburzeń psychicznych i psychosomatycznych. Szeroko rozumiane zaburzenia psychiczne u dzieci i młodzieży stanowią poważny problem zdrowotny, aczkolwiek statystyki dotyczące tej kwestii są w naszym kraju niepełne i fragmentaryczne, bowiem wiele osób pozostaje poza profesjonalną opieką psychiatryczną. Szacuje się, że zaburzenia zdrowia psychicznego dotyczą 10-20\% dzieci i młodzieży (Namysłowska 2013), a do najczęściej rozpoznawanych należą: zaburzenia rozwojowe (specyficzne zaburzenia kompetencji językowych, umiejętności szkolnych, funkcji motorycznych), zaburzenia nerwicowe związane ze stresem i występujące pod postacią nieprawidłowości somatycznych oraz zaburzenia afektywne (Tabak 2014). Za niezwykle niepokojące należy uznać ostatnie dane opublikowane przez Główny Urząd Statystyczny, z których wynika, że w grupie wiekowej 15-19 lat przyczyną prawie co piątego zgonu dziecka był zamach samobójczy, a samobójstwa dzieci i młodzieży stanowiły 12,2\% ogółu samobójstw w Polsce (GUS 2011). U znacznej części dzieci i młodzieży obserwuje się ponadto problem zaburzeń psychosomatycznych, a wyniki międzynarodowych badań ankietowych nad zachowaniami zdrowotnymi młodzieży szkolnej HBSC (Health Behaviour in School-aged Children. WHO Collaborative Study) wskazują na narastającą wraz z wiekiem częstotliwość występowania takich objawów, jak: bóle głowy, bóle pleców, przygnębienie, zdenerwowanie i rozdrażnienie (Mazur, Małkowska-Szkutnik 2011, s. 68-84);

- utrzymywanie się niekorzystnych trendów w zakresie zażywania przez młodzież substancji psychoaktywnych (w tym dopalaczy);

2 Z reprezentatywnego badania Instytutu Żywienia i Żywności przeprowadzonego w 2010 roku wynika, że nadwaga i otyłość dotyczyły łącznie 23,7\% chłopców i 22,8\% dziewcząt w wieku 9 lat, a odsetki te zwiększyły się o ok. 2\% w ciągu 3 lat. Dane z 2013 roku pokazują, że w odniesieniu do omawianego zjawiska nadal utrzymuje się tendencja wzrostowa - nadmierną masę ciała wykazywało 28\% chłopców i 22\% dziewcząt w wieku szkolnym (Jarosz 2013, s. 9). 
- $\quad$ utrzymywanie się nieprawidłowych tendencji w zakresie przejawiania zachowań związanych ze sposobem odżywiania, aktywnością fizyczną i ilością czasu spędzanego przed komputerem i telewizorem. Do niekorzystnych wskaźników ujawnianych w licznych badaniach dotyczących tego tematu warto dodać następujące: pierwsze śniadanie przed wyjściem do szkoły zjada zaledwie co drugi uczeń, zaś drugie śniadanie przyniesione $\mathrm{z}$ domu, które zgodnie $\mathrm{z}$ zasadami racjonalnego żywienia winno być spożyte ok. 3-4 godziny po pierwszym posiłku, zjada zaledwie ok. $42 \%$ dzieci - pozostałe korzystają ze sklepiku szkolnego. Co więcej, według opinii nauczycieli z placówek uczestniczących w ostatnich latach w projekcie „Zachowaj Równowagę jedynie 40\% uczniów szkół podstawowych oraz 7\% (!!!) uczniów gimnazjów uczestniczy w 95\% w zajęciach wychowania fizycznego (Jarosz 2013, s. 9-10). Należy mieć nadzieję, że wprowadzone ostatnio regulacje w zakresie wystawiania zwolnień lekarskich z lekcji wychowania fizycznego wpłyną na poprawę tej sytuacji, bowiem aktualne dane dotyczące wskaźników sprawności fizycznej dzieci i młodzieży szkolnej są alarmujące.

\section{UWARUNKOWANIA PROCESU PROMOCJI ZDROWIA W SZKOLE}

Promocja zdrowia w szkole to proces, którego przebieg jest uwarunkowany z jednej strony szeregiem czynników związanych ze szkołą, z drugiej zaś czynnikami natury społeczno-kulturowej tworzącymi kontekst podejmowanych przez szkołę działań. Wśród tych pierwszych można wyróżnić czynniki natury formalnej, edukacyjnej, organizacyjnej i osobowej.

Uwarunkowania natury formalnej należy odnosić do obowiązujących w systemie szkolnictwa aktów prawnych, które regulują pracę i funkcjonowanie szkoły na płaszczyźnie edukacyjnej i organizacyjnej. W odniesieniu do działalności edukacyjnej zasadniczym dokumentem jest podstawa programowa kształcenia ogólnego $^{3}$, która obliguje szkołę do osiągania efektów kształcenia w zakresie fundamentalnego komponentu promocji zdrowia, jakim jest edukacja zdrowotna. Odpowiednim regulacjom prawnym podlegają też zdrowotne aspekty organizacji pracy i życia szkoły (np. dzienne i tygodniowe rozkłady lekcji, przerwy międzylekcyjne, żywienie w szkole) oraz funkcjonowanie środowiska fizycznego szkoły - jej architektura, wyposażenie, najbliższe sąsiedztwo, warunki sanitarno-higieniczne

3 Aktualnie obowiązuje Rozporządzenie Ministra Edukacji Narodowej z 23 grudnia 2008 r. $w$ sprawie podstawy programowej wychowania przedszkolnego oraz kształcenia ogólnego w poszczególnych typach szkót (Dz. U. 2009, nr 4, poz. 17). 
czy zabezpieczenie uczniów przed wypadkami i urazami. Można zatem zasadnie twierdzić, że idea promocji zdrowia w szkole jest odpowiednio usankcjonowana prawem oświatowym.

Czynniki wpływające na przestrzeń edukacyjną wynikają z założeń programowych szkolnej edukacji zdrowotnej, w których zostało wskazane modelowe rozwiązanie w zakresie sposobu realizacji związanych z nią treści kształcenia. Rozwiązanie to obejmuje połączenie dwóch modeli kształcenia: modelu przedmiotu wiodącego, jakim jest wychowanie fizyczne, $\mathrm{z}$ modelem treści rozproszonych, które zostały rozlokowane w różnych przedmiotach ogólnokształcących.

W założeniach programowych przedmiotu wychowanie fizyczne zapisano, że pełni on ważne funkcje edukacyjne, rozwojowe i zdrowotne. Celem prowadzonych zajęć ma być wspieranie rozwoju fizycznego, psychicznego i społecznego oraz zdrowia uczniów, uświadomienie im potrzeby aktywności fizycznej i jej związku ze zdrowiem, kształtowanie nawyku aktywności fizycznej oraz szeregu umiejętności sprzyjających zapobieganiu chorobom oraz trosce o zdrowie i pielęgnowaniu go w okresie całego życia. W efektach kształcenia odnoszących się do edukacji zdrowotnej na I i II etapie edukacyjnym zostały uwzględnione zagadnienia dotyczące higieny, bezpiecznego zachowania się w różnych sytuacjach, odżywiania oraz profilaktyki chorób, zaś efekty kształcenia na III i IV etapie edukacyjnym obejmują szerokie spektrum zagadnień, których wprowadzenie ma służyć kształtowaniu u uczniów kompetencji osobistych i społecznych umożliwiających prozdrowotny styl życia. Należy przy tym podkreślić, że w podstawie programowej wychowania fizycznego zdrowie zostało potraktowane w sposób holistyczny. Mamy tu bowiem do czynienia z jednej strony z obszernym wykazem wymagań szczegółowych dotyczących sportu, profilaktyki medycznej, wybranych aspektów prozdrowotnego stylu życia (w tym treningu zdrowotnego), zapobiegania szkodom zdrowotnym związanym ze stosowaniem substancji psychoaktywnych, przeciwdziałania chorobom cywilizacyjnym, sportu czy diagnozy sprawności fizycznej, z drugiej zaś wskazano na potrzebę osiągania efektów kształcenia zgodnych z założeniami współczesnej filozofii zdrowia oraz szeroko rozumianego zdrowia psychospołecznego i duchowego (Podstawa programowa $z$ komentarzami... 2011).

$\mathrm{W}$ ramach modelu treści rozproszonych wymagania szczegółowe odnoszące się bezpośrednio bądź pośrednio do zdrowia można znaleźć przede wszystkim w programach takich przedmiotów, jak: przyroda, biologia, wychowanie do życia w rodzinie, język obcy nowożytny, edukacja dla bezpieczeństwa oraz wiedza o społeczeństwie. Opierając się na analizie podstaw programowych tych przedmiotów ${ }^{4}$,

${ }^{4}$ W niniejszych rozważaniach przyjmuję, że zagadnienia z zakresu edukacji seksualnej, jakkolwiek wyraźnie związane z holistycznie rozumianym zdrowiem, wchodzą w skład odrębnej dziedziny edukacji, toteż nie biorę ich pod uwagę w prezentowanych analizach. 
można uznać, że w ramach każdego z nich powinny być osiągane efekty kształcenia w zakresie zdrowia psychicznego, społecznego i duchowego, jednak wymagania szczegółowe i treści dotyczące zdrowia fizycznego zostały przypisane przede wszystkim do przedmiotu biologia/przyroda ${ }^{5}$.

Przebieg procesu promocji zdrowia w szkołach uwarunkowany jest również czynnikami natury organizacyjnej, które są związane z realizowaną w placówkach edukacyjnych polityką zdrowotną. Obejmuje ona: (1) działania zmierzające do udostępniania uczniom warunków sprzyjających ich bezpieczeństwu fizycznemu i higienie pracy umysłowej oraz przejawianiu zachowań prozdrowotnych w zakresie odżywiania się oraz szeroko rozumianej aktywności fizycznej; (2) działania mające na celu zapobieganie problemom zdrowotnym uczniów, np. realizowanie programów profilaktycznych; (3) działania szkoły związane z doskonaleniem przez nauczycieli kompetencji w zakresie edukacji zdrowotnej.

Udział czynników natury osobowej w przebiegu procesu promocji zdrowia w szkole należy wiązać z nauczycielem, bowiem jego zaangażowanie w promowanie zdrowia somatycznego i psychospołecznego uczniów jest niejako wpisane w pełnioną rolę zawodową. Każdy nauczyciel, bez względu na rodzaj przygotowania merytorycznego do nauczania określonego przedmiotu, powinien przybliżać młodym ludziom prozdrowotne wzorce stylu życia oraz podejmować działania edukacyjne ukierunkowane na umacnianie zdrowia uczniów w różnych sytuacjach edukacyjnych. Jednak zgodnie z założeniami podstawy programowej uważa się, że szczególny rodzaj kompetencji w tym zakresie powinni posiadać nauczyciele wychowania fizycznego oraz tych przedmiotów ogólnokształcących, w odniesieniu do których wymagania i treści programowe są bezpośrednio bądź pośrednio związane ze zdrowiem.

Spojrzenie na funkcjonowanie ucznia w szkole z perspektywy ekologicznej pozwala uznać, że niezwykle istotnym czynnikiem warunkującym efektywność procesu promocji zdrowia jest specyfika środowiska psychospołecznego danej placówki. Odwołując się do strukturalnych ujęć pojęcia „klimatu szkoły”, należy

5 Wybrane zagadnienia związane ze zdrowiem fizycznym zostały uwzględnione również w przedmiotach: edukacja dla bezpieczeństwa, chemia oraz język obcy nowożytny. W wymaganiach ogólnych chemii dla szkół ponadgimnazjalnych zapisano, że uczeń „posługuje się zdobytą wiedza chemiczną w życiu codziennym w kontekście dbałości o własne zdrowie", zaś w wymaganiach szczegółowych został umieszczony blok Chemia wspomaga nasze zdrowie. Chemia w kuchni, w którym znajdują się zagadnienia dotyczące leczniczych i toksycznych właściwości niektórych leków oraz działania wybranych substancji psychoaktywnych. Natomiast w wymaganiach szczegółowych chemii dla gimnazjum znalazł się zapis mówiący, iż uczeń „opisuje negatywne skutki działania alkoholu etylowego na organizm”. Z kolei w ramach zajęć z języka obcego nowożytnego podczas wprowadzania słownictwa i struktur językowych powinny być realizowane treści dotyczące żywienia, sportu i rekreacji, higieny, uzależnień oraz symptomatologii i leczenia wybranych chorób. 
zwrócić szczególną uwagę na jego wymiar edukacyjny i społeczny analizowany z perspektywy tego, jak postrzegają go uczniowie. Mówiąc o wymiarze edukacyjnym, mamy na uwadze przede wszystkim kompatybilność między stopniem obciążenia nauką szkolną a możliwościami sprostania przez ucznia stawianym mu wymaganiom oraz stosowane przez nauczycieli praktyki w zakresie dokonywania oceny osiągnieć szkolnych. W zależności od wykorzystywanych strategii edukacyjnych czynniki te mogą być źródłem zasobów dla zdrowia psychicznego ucznia - wzmacniać jego poczucie wartości, podnosić samoocenę, motywować do nauki, sprzyjać zdobywaniu pozytywnych doświadczeń - lub generować lęki szkolne, poczucie bezradności i zawyżony poziom szkolnego dysstresu. Społeczny wymiar klimatu klasy/szkoły wiąże się natomiast w omawianym kontekście z efektywnością procesu komunikacji na linii nauczyciel-uczeń oraz postrzeganiem przez uczniów nauczycielskiego wsparcia. Uwzględniając całą złożoność zależności między środowiskiem psychospołecznym szkoły a zdrowiem uczniów, można w tym miejscu zasadnie twierdzić, że osoba nauczyciela przez ujawniany w codziennych sytuacjach życia szkolnego styl komunikowania się z uczniami pełni szczególną rolę w promocji ich zdrowia fizycznego i psychospołecznego.

W analizach uwarunkowań promocji zdrowia w szkole nie sposób pominąć wreszcie czynników natury społeczno-kulturowej, które tworzą kontekst, w jakim ten proces jest realizowany. Należy do nich zaliczyć przekazy medialne, teksty kultury popularnej promujące ideologię konsumpcji oraz lansujące obowiązujący ideał sylwetki i urody, jak również społecznie usankcjonowane sposoby estetyzowania i modyfikowania ciała.

Efektem medialnej manipulacji i indoktrynacji jest powszechnie dziś obecne w świadomości społecznej przekonanie, że kreowany w reklamie i mediach wizerunek ciała jest osiągalny pod warunkiem konsumowania określonych produktów i usług oraz stosowania „odmedialnych” schematów dbania o ciało. Doprowadziło to do ukształtowania się świadomości ciała jako obiektu indywidualnego zarządzania i modyfikacji przez stosowanie różnorodnych, bardziej bądź mniej powszechnych zabiegów: makijażu, piercingu, opalania się czy modelowania sylwetki w centrach sportu i rekreacji bądź klubach fitness. Niemal wszechobecny kult ciała wraz $\mathrm{z}$ upowszechnianiem się przekonania o możliwości kontrolowania naturalnej cielesności spowodował, że ciało stało się dla współczesnego człowieka, zwłaszcza młodego, socjalizowanego w kulturze konsumpcji, ważnym źródłem formowania się jednostkowej tożsamości (por. Jakubowska 2009, s. 154 i nast.; Shilling 2010, s. 242). Rezultatem tych przemian jest znamienne dla kultury współczesnej zjawisko „zamykania się" motywacji do podejmowania praktyk prozdrowotnych w oczekiwaniach dotyczących wizerunku ciała. W efekcie zdrowotne aspekty takiej aktywności ulegają przesunięciu na dalszy plan i, co więcej, młodzi ludzie 
w imię korzyści dla ciała są gotowi do prezentowania zachowań destrukcyjnych dla zdrowia.

Należy w końcu zauważyć, że środki masowego przekazu, przede wszystkim Internet, stanowią dziś ważne, a dla wielu młodych ludzi wręcz bezprzecznie wiarygodne źródło informacji dotyczących zdrowia, choroby i zachowań zdrowotnych, czego konsekwencją jest nabywanie przez nich pseudoeksperckiej wiedzy w tym zakresie. Na wielką skalę „edukują” umasawiane przez media treści kultury popularnej i reklam, przy czym te drugie z uwagi na swoją „misję” zwykle zakłamują zarówno prawdy naukowe, jak i rzeczywistość. Za szczególnie kontrowersyjne należy uznać te reklamy, które nie tylko przekazują określony zestaw informacji, lecz także dzięki sile zawartego przekazu kształtują u młodych ludzi niebezpieczne w skutkach przekonania i oczekiwania zdrowotne. Czytelnym przykładem są reklamy niektórych suplementów diety, piwa czy leków dostępnych bez recepty, zwłaszcza przeciwbólowych i przeznaczonych na dolegliwości gastryczne. Przekaz marketingowy związany z produktami branży farmaceutycznej sprzyja ponadto promowaniu biomedycznego radzenia sobie z najdrobniejszymi dolegliwościami.

Biorąc pod uwagę wspomniane wyżej wyróżniki kontekstu społeczno-kulturowego, w jakim szkoła realizuje proces promocji zdrowia, można twierdzić, że kontekst ten stanowi zarówno barierę, jak i wyzwanie związane z podejmowanymi w szkole działaniami.

\section{BARIERY PROMOCJI ZDROWIA W SZKOLE}

Zarysowana powyżej charakterystyka uwarunkowań procesu promocji zdrowia związanych ze szkołą pozwala na wskazanie trzech zasadniczych obszarów, w których pojawiają się bariery ograniczające efektywność działań podejmowanych w tym zakresie. Zaliczyć do nich należy przeszkody związane z: treściami podstawy programowej odnoszącymi się do edukacji zdrowotnej, kompetencjami nauczycieli oraz funkcjonowaniem środowiska szkoły na płaszczyźnie organizacyjnej i psychospołecznej.

\section{BARIERY ZWIĄZANE Z WARSTWĄ TREŚCIOWĄ PODSTAWY} PROGRAMOWEJ W ZAKRESIE EDUKACJI ZDROWOTNEJ

Przedstawiony wcześniej skrótowy obraz założeń programowych w zakresie szkolnej edukacji zdrowotnej wskazuje, że teoretyczną podbudową do ich projektowania była holistyczna i systemowa koncepcja zdrowia i jego uwarunkowań. W podstawie programowej duży nacisk położono na wymagania dotyczące zagadnień 
związanych z promocją zdrowia psychicznego i społecznego, obligując nauczycieli do kształtowania u uczniów szeregu kompetencji psychospołecznych umożliwiających efektywne i sprzyjające utrzymaniu dobrostanu radzenie sobie w codziennym życiu. Uwzględniono także systemowe powiązania zdrowia z fizycznym i społecznym środowiskiem życia człowieka oraz koncepcję wieloczynnikowych uwarunkowań tego środowiska z naciskiem na zasadniczą rolę prozdrowotnego, opartego na aktywności fizycznej, stylu życia. W tym kontekście można twierdzić, że w szkolnym programie kształcenia dzieci i młodzieży, w obszarze zagadnień związanych ze zdrowiem i chorobą został przezwyciężony obowiązujący niemal przez trzy stulecia paradygmat kartezjański wraz z charakterystycznym dla niego biomedycznym myśleniem o zdrowiu.

Dokonanie pogłębionej analizy założeń programowych z perspektywy doświadczanej współcześnie w naszym kręgu cywilizacyjnym kultury konsumpcji i kultu ciała prowadzi jednak do wniosku, że cele edukacji zdrowotnej zapisane w podstawie programowej wielu przedmiotów ogólnokształcących dotyczą przede wszystkim kształtowania psychospołecznego wymiaru zdrowia uczniów. Natomiast zarówno kwestia kulturowych odniesień ludzkiego ciała jako realnej podstawy fenomenu zdrowia, jak i przygotowania młodego człowieka do radzenia sobie z kultem ciała napędzanym przez kulturę konsumpcji, nie została w należyty sposób zaakcentowana ${ }^{6}$. Można zatem twierdzić, że koncepcja szkolnej edukacji zdrowotnej nie spełnia w wystarczającym stopniu potrzeb ani oczekiwań młodych ludzi. Potwierdzają to też wyniki badań empirycznych ${ }^{7}$, w których uczniowie bardzo krytycznie oceniają treści zawarte w programach kształcenia z zakresu edukacji zdrowotnej. Co więcej, badani podkreślają, że treści te są anachroniczne i słabo korespondują ze sposobem postrzegania świata młodych ludzi (Wójtewicz 2014, s. 176 i nast.).

\section{BARIERY TKWIĄCE W KOMPETENCJACH NAUCZYCIELI}

Udział w procesie promowania zdrowia somatycznego i psychospołecznego uczniów jest wpisany w rolę zawodową każdego nauczyciela, a wyznacznikiem jego gotowości do wykonywania związanych z tym udziałem zadań jest posiadanie określonych kompetencji. Analiza treści programów studiów przygotowujących do zawodu

${ }^{6}$ W podstawie programowej przedmiotów ogólnokształcących wymagania szczegółowe w zakresie edukacji zdrowotnej odnoszone wprost do kulturowych znaczeń ciała znalazły się jedynie w przedmiocie przyroda realizowanym w szkołach ponadgimnazjalnych.

7 Odnoszę się do badań Anny Wójtewicz, które były ukierunkowane na ocenę realiów prowadzenia szkolnej edukacji zdrowotnej w kontekście przemian społecznej roli ciała. Badaniami zostało objętych 491 uczniów w wieku gimnazjalnym i licealnym na terenie kujawsko-pomorskich szkół należących do sieci Szkół Promujących Zdrowie (Wójtewicz 2014). 
nauczyciela pokazuje, że jeżeli poziom kompetencji będzie mierzony wskazanymi w tychże programach efektami kształcenia, to mogą one stanowić kolejną barierę dla promocji zdrowia w szkole.

W Polsce kształcenie nauczycieli przygotowujące do realizowania w szkole obowiązkowego przedmiotu wychowanie fizyczne jest prowadzone $\mathrm{w}$ formie studiów stacjonarnych i niestacjonarnych I i II stopnia oraz studiów podyplomowych na uczelniach publicznych i niepublicznych w ramach kierunku wychowanie fizyczne. $\mathrm{Z}$ analizy programów studiów obowiązujących na wszystkich działających w Polsce publicznych uczelniach wychowania fizycznego oraz udostępnionych przez nie sylabusów wynika, że podejście ich autorów do założeń podstawy programowej kształcenia ogólnego, które nakładają na nauczyciela wychowania fizycznego obowiązek osiągania efektów kształcenia w zakresie edukacji zdrowotnej, jest dość swobodne, zaś potrzeba wyposażenia przyszłych nauczycieli w wiedzę i umiejętności w zakresie promocji zdrowia w szkole jest zaspokajana w bardzo niewielkim stopniu. Świadczą o tym m.in. następujące wnioski i ustalenia:

- przedmiot edukacja zdrowotna jest realizowany (w wymiarze ok. 30 godzin) na studiach I lub II stopnia, co oznacza, że nie wszyscy absolwenci studiów I stopnia podejmujący pracę w szkole mają szansę w tym kursie uczestniczyć; ;

- biorąc pod uwagę bardzo rozbudowane na omawianym kierunku studiów efekty kształcenia w zakresie zagadnień biomedycznych, można się zastanawiać nad zasadnością doboru treści kształcenia uwzględnionych w sylabusach przedmiotu edukacja zdrowotna. Skoncentrowane są one bowiem przede wszystkim wokół zagadnień merytorycznych (związanych z współczesną koncepcją zdrowia, racjonalnym żywieniem i zaburzeniami odżywiania się, zdrowiem psychospołecznym oraz profilaktyką uzależnień) przy jednoczesnym marginalnym traktowaniu dydaktyki edukacji zdrowotnej. Brak jest też w analizowanych sylabusach treści związanych z pedagogicznymi aspektami zjawiska „zawłaszczania” ciała i zdrowia, zamienianie ich w przedmioty konsumpcji przez przekazy medialne (przede wszystkim reklamę) ${ }^{10}$;

8 Co więcej, można przypuszczać, że jedynie nieliczni studenci są dokładnie zaznajamiani z zadaniami związanymi z rolą lidera edukacji zdrowotnej i promocji zdrowia w szkole. Zagadnienia temu poświęcone można bowiem odnaleźć w sylabusie kursu Teoretyczne przesłanki nowej podstawy programowej realizowanego w jednej tylko uczelni publicznej w Polsce na kierunku wychowanie fizyczne.

9 W większości programów studiów na kierunku wychowanie fizyczne zagadnienia związane z żywieniem człowieka są ujmowane w programach przedmiotów specjalistycznych, może więc budzić wątpliwości zasadność realizowania tych treści w ramach przedmiotu edukacja zdrowotna.

10 Warto dodać, że tylko w jednym sylabusie przedmiotu edukacja zdrowotna prowadzonego na 
- w omawianych programach studiów nie został uwzględniony kurs promocji zdrowia, a związane z nią treści ujęto jedynie w niektórych sylabusach przedmiotu edukacja zdrowotna, i to w bardzo skrótowej formie ${ }^{11}$. Co prawda, w jednej z uczelni zajęcia dotyczące wieloaspektowej problematyki promocji zdrowia zostały zaplanowane na studiach II stopnia, ale nie są one przeznaczone dla wszystkich studentów, a jedynie dla specjalności promocja zdrowia ${ }^{12}$, podczas gdy na specjalności szkolne wychowanie fizyczne w programie studiów nie przewidziano żadnego przedmiotu, który wprowadzałby zagadnienia merytorycznie z promocją zdrowia związane;

- w programach studiów kilku polskich uczelni przygotowujących nauczycieli wychowania fizycznego oferowany jest przedmiot teoria edukacji zdrowotnej uwzględniający treści, które byłyby bardzo przydatne w przyszłej pracy zawodowej absolwentów. Dotyczą one bowiem m.in. pedagogiki zdrowia, interpretacji kulturowej rzeczywistości, praktycznego przygotowania studenta do realizacji treści edukacji zdrowotnej oraz animacji aktywności rekreacyjnej, zabawowej, turystycznej i sportowej, jak również metodyki przygotowywania projektów społecznych. Okazuje się jednak, że oferta ta skierowana jest jedynie do studentów wybierających specjalność edukacja fizyczna w późnej dorosłości. Można się w tym miejscu zastanawiać, co kieruje autorami omawianych programów studiów, którzy uzależniają zasadność gruntownego przygotowania absolwenta kierunku wychowanie fizyczne do udziału w procesie edukacji zdrowotnej i promocji zdrowia od etapu życia adresatów oddziaływań edukacyjnych (deprecjonują przy tym okresy dzieciństwa i młodości, na które przypada spełnianie obowiązku szkolnego).

Omawiana kwestia staje się jeszcze bardziej czytelna, gdy spojrzeć na ofertę uczelni wychowania fizycznego dla czynnych nauczycieli chcących zdobyć uprawnienia do nauczania wychowania fizycznego jako tzw. drugiego przedmiotu. Otóż są nią studia podyplomowe realizowane zgodnie z programami, w których zagadnienia dotyczące edukacji zdrowotnej i promocji zdrowia w szkole są reprezentowane w zdecydowanej większości przypadków bardzo marginalnie.

kierunku wychowanie fizyczne w publicznej uczelni wychowania fizycznego znalazł się zapis: „Zdrowie a media i reklama. Jak szukać wiarygodnych informacji na temat zdrowia i praw konsumenta”.

11 Ponadto w jednej z uczelni na studiach I stopnia zaplanowano do realizacji przedmiot higiena szkolna, którego treści nawiązują do niektórych obszarów promocji zdrowia w szkole.

$12 \mathrm{~W}$ programie studiów na specjalności promocja zdrowia zostały uwzględnione m.in. takie przedmioty, jak: zdrowie publiczne i podstawy epidemiologii, planowanie, monitorowanie i ewaluacja w promocji zdrowia, zagrożenia zdrowotne i choroby cywilizacyjne, teoretyczne i praktyczne podstawy lokalnych i globalnych programów promocji zdrowia oraz psychologia zdrowia. 
Odnosząc kwestię przygotowania merytorycznego w zakresie edukacji zdrowotnej do nauczycieli przedmiotów ogólnokształcących, które bezpośrednio bądź pośrednio wiążą się z edukacją zdrowotną, należy zauważyć, że jego wysoki poziom jest niewątpliwie zapewniony jedynie w przypadku nauczycieli biologii/przyrody. Osoby przygotowujące się do wykonywania zawodu nauczyciela, legitymujące się ukończeniem innych kierunków studiów mają bowiem możliwość realizowania omawianych treści w zdecydowanie mniejszym zakresie, określonym przez Standardy kształcenia przygotowujace do wykonywania zawodu nauczyciela ${ }^{13}$. Analiza treści kształcenia zawartych tam w module Przygotowanie w zakresie psychologiczno-pedagogicznym pokazuje, że jakkolwiek zakres zaplanowanych przez ustawodawcę zagadnień związanych z promocją zdrowia psychospołecznego uczniów jest bardzo rozbudowany, to w odniesieniu do kwestii dotyczących zdrowia somatycznego wydaje się on raczej zawężony. Co więcej, na realizację tych treści można przeznaczyć znikomą liczbę godzin. Ponadto zupełnie nieobecna jest tu problematyka dotycząca społeczno-kulturowych aspektów cielesności i pedagogiki ciała. Zarówno w ogólnych treściach kształcenia analizowanego modułu, jak i w treściach przypisanych do poszczególnych etapów edukacyjnych został zastosowany niezwykle ogólnikowy sposób formułowania haseł programowych, co budzi obawę, że studenci nie zostaną wyposażeni w wiedzę i umiejętności niezbędne do efektywnego udziału w promowaniu zdrowia uczniów. Można mieć zatem uzasadnione wątpliwości co do zakresu profesjonalnej wiedzy o zdrowiu i jego zaburzeniach u nauczycieli, którzy są formalnie zobligowani do realizacji niektórych zagadnień w tym obszarze ${ }^{14}$.

\section{BARIERY ZWIĄZANE Z FUNKCJONOWANIEM ŚRODOWISKA SZKOŁY}

Efektywność działań w zakresie promocji zdrowia uczniów zależy w dużej mierze od poziomu świadomości zdrowotnej nauczycieli i dyrektorów szkół oraz ich poczucia odpowiedzialności za wychowanie dzieci i młodzieży, ale okazuje się, że częstokroć stają oni przed barierami, których pokonywanie wymaga dużego determinizmu i nie zawsze mają do tego kompetencje. Można tu wskazać przede wszystkim na bariery finansowe ograniczające działania szkoły związane z zapewnianiem uczniom warunków sprzyjających zachowaniom prozdrowotnym w zakresie aktywności fizycznej. W wielu polskich szkołach, a zwłaszcza tych zlokalizowanych na terenach zaniedbanych ekonomicznie, zaplecze sportowe i rekreacyjne nie spełnia

\footnotetext{
13 Rozporządzenie Ministra Nauki i Szkolnictwa Wyższego z dnia 17 stycznia 2012 r. w sprawie standardów kształcenia przygotowującego do wykonywania zawodu nauczyciela.

14 Kwestia ta wydaje się szczególnie czytelna w odniesieniu do nauczycieli języka obcego nowożytnego, od których oczekuje się specjalistycznej wiedzy na temat m.in. zasad żywienia człowieka, uzależnień oraz symptomatologii i leczenia chorób.
} 
wymaganych standardów, co skutkuje niezwykle ubogą ofertą zajęć sportowych nie tylko w ramach zajęć pozalekcyjnych, ale również w trakcie lekcji wychowania fizycznego. Względami finansowymi uwarunkowane jest też zazwyczaj odchodzenie od korzystania w szkołach z programów profilaktycznych rekomendowanych przez resort edukacji na rzecz wprowadzania programów o nieudokumentowanej skuteczności oferowanych przez różne podmioty specjalizujące się w działalności profilaktycznej bądź opracowywanych przez samych nauczycieli (por. Gaweł 2014, s. 234).

Osobna kwestia dotyczy rozwiązań w zakresie żywienia uczniów w szkole. W związku z wprowadzeniem od września 2015 roku regulacji prawnych ograniczających uczniom dostęp do pokarmów, których spożywanie pociąga za sobą ryzyko problemów zdrowotnych (produktów tłustych, słonych i słodzonych) ${ }^{15}$, a zwłaszcza otyłości, przez ich wyeliminowanie ze sklepików i stołówek szkoła została niejako ubezwłasnowolniona w swoich działaniach na rzecz promowania zdrowych wzorców żywienia. Co więcej, wprowadzone przez resort edukacji ograniczenia często stają się powodem opracowywania różnorodnych strategii, które pozwalają ominąć te przepisy nie tylko uczniom, ale także rodzicom, co prowadzi do obniżenia autorytetu szkoły jako drugiego po rodzinie środowiska wychowawczego.

Bariery ograniczające efektywność procesu promocji zdrowia związane są wreszcie z funkcjonowaniem środowiska psychospołecznego szkoły w tym jego obszarze, który jest kreowany przez nauczycieli. Wyniki licznych badań dają podstawę, by sądzić, że znaczącą przeszkodę w promowaniu zdrowia uczniów stanowią prezentowane przez nauczycieli niepartnerskie wzorce komunikowania się (por. Sufa 2005), które są obserwowane zwłaszcza na gimnazjalnym i ponadgimnazjalnym etapie kształcenia.

\section{PODSUMOWANIE}

Promocja zdrowia wraz z wpisaną w nią edukacją zdrowotną stanowi jedno z najważniejszych zadań szkoły nie tylko z punktu widzenia wielostronnego rozwoju, przebiegu procesów tożsamościowych oraz fizycznego i psychospołecznego dobrostanu uczniów, ale także w kontekście zasobów dla ich zdrowia w całym cyklu życia. W obliczu wyzwań stojących przed promocją zdrowia oraz barier ograniczających możliwości podejmowania efektywnych działań można zasadnie twierdzić, że nie jest ona zadaniem prostym. Jakkolwiek bowiem idea jej przyświecająca jest

15 Rozporzadzenie Ministra Zdrowia z dnia 26 sierpnia 2015 r. w sprawie grup środków spo$\dot{z} y w c z y c h$ przeznaczonych do sprzedaży dzieciom i młodzieży $w$ jednostkach systemu oświaty oraz wymagań, jakie musza spelniać środki spożywcze stosowane $w$ ramach żywienia zbiorowego dzieci i młodzieży w tych jednostkach (Dz. U. z 28 sierpnia 2015 r., poz. 1256). 
odpowiednio usankcjonowana prawem oświatowym, to sprawą otwartą pozostaje kwestia realizacji założeń promocji zdrowia w praktyce życia szkolnego. Zważywszy na bariery tkwiące w ograniczeniach finansowych, które utrudniają podejmowanie przez szkołę działań promujących zdrowie uczniów, niezbędnym wydaje się wsparcie placówek na poziomie systemowym. Równie istotna jest jednak potrzeba dyskusji nad rekonstrukcją założeń programowych szkolnej edukacji zdrowotnej. Wobec zarysowanych tu ram wpływu mediów i kultury popularnej na kształtowanie się u młodych ludzi postaw wobec ciała i zdrowia szczególnym wyzwaniem dla szkolnej edukacji zdrowotnej jest przygotowanie uczniów do radzenia sobie z promowanym przez ideologię konsumpcji kultem ciała, a tym samym do takiego funkcjonowania w „społeczeństwie somatycznym”, które będzie sprzyjało ich zdrowiu we wszystkich jego wymiarach. Jednym z priorytetów edukacji zdrowotnej winno się w związku z tym stać przekonywanie uczniów, że chociaż człowiek jest ciałem i posiada ciało, nad którym może w pewnym stopniu zapanować, to nade wszystko stanowi ono materialny fundament zdrowia, zaś zdrowie jest nośnikiem wartości decydujących o sposobach doświadczania ciała. Trzeba przy tym podkreślić, że warunkami efektywności szkolnej promocji zdrowia są: odpowiednio uformowana świadomość zdrowotna nauczycieli oraz posiadanie przez nich kompetencji w zakresie odczytywania potrzeb i problemów zdrowotnych uczniów, rozpoznawania lansowanych przez kulturę popularną trendów w postrzeganiu ciała oraz projektowanie, organizowanie i realizowanie procesu edukacji zdrowotnej jako konstytutywnego elementu działań zmierzających do wzmacniania potencjału zdrowia młodych ludzi.

\section{LITERATURA}

Gaweł A., 2013, Human health as a context of the andragogical discourse. W: M. Radovan, M. Kościelniak (red.), Lifelong learning today. New areas. Contexts. Practices. Kraków, Wydawnictwo UJ, 27-39.

Gaweł A., 2014, Zasoby zdrowotne młodzieży gimnazjalnej w kontekście ekosystemu szkoły. Kraków, Wydawnictwo UJ.

GUS, 2011, Zdrowie dzieci i młodzieży w Polsce w 2009 roku. Studia i analizy statystyczne. Kraków, US.

Jakubowska H., 2009, Socjologia ciała. Poznań, Wydawnictwo Naukowe UAM.

Jarosz M. (red.), 2013, Ogólnopolskie działania w zakresie zwalczania nadwagi i otyłości, ze szczególnym uwzględnieniem dzieci i młodzieży. Warszawa, Instytut Żywienia i Żywności. 
Mazur J., Małkowska-Szkutnik A. (red.), 2011, Wyniki badań HBSC 2010. Raport techniczny. Warszawa, Instytut Matki i Dziecka.

Namysłowska I., 2013, Zdrowie psychiczne dzieci i młodzieży w Polsce - stan rozwoju opieki psychiatrycznej i zadania na przyszłość. „Postępy Nauk Medycznych”, nr $1,4-9$.

Podstawa programowa $z$ komentarzami, t. 8: Wychowanie fizyczne i edukacja dla bezpieczeństwa w szkole podstawowej, gimnazjum i liceum [pozyskano z: http:// men.gov.pl/wpcontent/upload/2011/02/men_tom_8.pdf, dostęp: 16.07.2015].

Rubacha K., 2003, Edukacja jako przedmiot pedagogiki i jej subdyscyplin. W: Z. Kwieciński, B. Śliwerski (red.), Pedagogika. Podręcznik akademicki, t. I. Warszawa, Wydawnictwo Naukowe PWN, 21-33.

Sufa B., 2005, Styl komunikowania się nauczyciela z uczniami a skuteczność porozumiewania się i współdziałania w klasie. W: E.A. Zwolińska (red.), Edukacja kreatywna. Bydgoszcz, Wydawnictwo Akademii Bydgoskiej, 142-150.

Shilling Ch., 2010, Socjologia ciała. Warszawa, Wydawnictwo Naukowe PWN.

Tabak I., 2014, Zdrowie psychiczne dzieci i młodzieży. Wsparcie dzieci i młodzieży w pokonywaniu problemów. „Studia BAS”, nr 2(38), 113-138.

Tchorzewski de A.M., 2006, Refleksje wokół aktualnego rozumienia wychowania zdrowotnego jako kategorii pojęciowej w naukach pedagogicznych. „Roczniki Państwowego Zakładu Higieny", t. 57, 9-16.

WHO, 1986, Ottawa Charter for Health Promotion. An International Conference on Health Promotion. The move towards a new public health, Ottawa Ontario Canada.

Wójtewicz A., 2014, Ciało w kulturze konsumpcji. Efektywność edukacji zdrowotnej na przykładzie sieci szkót promujacych zdrowie. Toruń, Wydawnictwo UMK.

\title{
SCHOOL AND TEACHER IN THE LIGHT OF THE CONTEMPORARY CHALLENGES FOR HEALTH PROMOTION OF CHILDREN AND YOUTH
}

\begin{abstract}
Health promotion in schools includes health education and actions aimed at creating an environment conducive to the physical and psychosocial health of students. This process is conditioned by educational and organizational factors and factors which are related to the competence of teacher. In fact today the particular context of actions taken by the school is created by a socio-cultural factors. The author analyzes the assumptions of health education program in school, academic curricula of teachers and selected aspects of the school environment and she sees in them the barriers to the effectiveness of health promotion in school.
\end{abstract}

Keywords: health promotion, health education, school. 